\title{
Prevalence of Helicobacter pylori Infection among Anemic School-Age Children in Egypt: A Cross-Sectional Population-Based Study
}

\author{
Tarek A. Abdelaziz ${ }^{10}$ Mohamed Almalky ${ }^{1}$ Diana Hanna ${ }^{1}$ Eman Gamal Baz ${ }^{1}$ \\ ${ }^{1}$ Department of Pediatrics, Faculty of Medicine, Zagazig University, \\ Address for correspondence Eman Gamal Baz, Department of \\ Sharkia, Egypt \\ Pediatrics, Faculty of Medicine, Zagazig University, Sharkia 44519, \\ J Child Sci 2021;11:e317-e326. \\ Egypt (e-mail: eman_albaz@yahoo.com).
}

\begin{abstract}
Anemia and Helicobacter pylori infection in school-age children are important public health problems. The association between $\mathrm{H}$. pylori infection and the development of anemia, especially iron deficiency anemia, has been previously studied and until now it is still a matter of argument. This study aimed to determine the prevalence of anemia and $H$. pylori infection among school-age children and to find the association between $H$. pylori infection and anemia in school-age children. We conducted this populationbased cross-sectional study in six Egyptian primary schools over a 12-month-period, including 1,200 students from all grades who fulfilled the inclusion criteria. The study participants were subjected to the following: medical history, clinical examination, and laboratory investigations included complete blood count and $\mathrm{H}$. pylori antigen in stool, and according to the level of hemoglobin $(\mathrm{Hb})$, we divided the students into two groups; the anemic group with $\mathrm{Hb}$ level $<11.5 \mathrm{~g} / \mathrm{dL}$ and nonanemic group with $\mathrm{Hb}$ level $\geq 11.5 \mathrm{~g} / \mathrm{dL}$, and the serum ferritin levels were measured only for the anemic group as the best indicator for iron status. The overall prevalence of $H$. pylori infection was $25 \%$. The overall prevalence of anemia was $13.25 \%$, of which hypochromic microcytic anemia represented $87.4 \%$ of the anemic group, and the mean ferritin level in the anemic group was $18.56 \pm 9.96 \mathrm{ng} / \mathrm{mL}$. The prevalence of anemia among $\mathrm{H}$. pyloriinfected patients $(62.3 \%)$ was significantly $(p<0.001)$ higher than in noninfected children (37.7\%). In the anemic group, the mean ferritin level in $\mathrm{H}$. pylori-infected children was significantly lower than the mean level in the noninfected children

\section{Keywords}

- anemia

- iron deficiency anemia

- Helicobacter pylori infection

- school-age children

- ferritin level $(p<0.001)$. Furthermore, the anemic group had a significantly higher incidence of $H$. pylori infection and a lower age $(p<0.001)$ in comparison with the nonanemic group. The dominant type of anemia in $H$. pylori-infected children was the microcytic hypochromic anemia, with a significantly higher incidence in comparison to other types of anemia $(p<0.001)$. The findings of this study demonstrate a significant association between $H$. pylori infection and anemia in school-aged children, especially iron deficiency anemia, as the incidence of $H$. pylori infection was greater in anemic children than in non-anemic children.
\end{abstract}

received

July 3, 2021

accepted after revision

October 12, 2021
DOI https://doi.org/

$10.1055 / \mathrm{s}-0041-1740465$.

ISSN 2474-5871. (c) 2021. The Author(s).

This is an open access article published by Thieme under the terms of the Creative Commons Attribution License, permitting unrestricted use, distribution, and reproduction so long as the original work is properly cited. (https://creativecommons.org/licenses/by/4.0/)

Georg Thieme Verlag KG, Rüdigerstraße 14, 70469 Stuttgart, Germany 


\section{Introduction}

Anemia is a global public health problem that corresponds to $24.8 \%$ of the population in both developing and developed countries and is assumed that $50 \%$ of the cases of anemia are due to iron deficiency (ID) but the proportion may vary among population groups and in different areas according to the local conditions. ${ }^{1}$ The main risk factors for iron deficiency anemia (IDA) include a low intake of iron, poor absorption of iron, and gastrointestinal (GI) bleeding due to different causes like celiac disease, parasitic infestations, peptic ulcer, and Helicobacter pylori infection. ${ }^{2-4}$

Most H. pylori infections are usually without clinical manifestation, particularly in poor communities. However, signs and symptoms associated with the disease are primarily due to gastric or duodenal inflammation. H. pylori infection developed during early childhood has been reported to have extradigestive consequences including the retardation of growth rate, the development of ID, or both. ${ }^{5}$

The relationship between $H$. pylori infection and development of ID or IDA has been largely studied and until now it is still a matter of argument despite many studies and metaanalysis that concluded a solid relationship is not only between infection, either symptomatic or not, and development of IDA but also between the eradication of infection and improvement of iron status in the subjects. On the other hand, some studies denied a relationship between infection with H. pylori and IDA. ${ }^{6}$

Meta-analyses of population studies suggest the contribution of ID to anemia could be smaller than the World Health Organization (WHO) estimate: $25 \%$ in children and $37 \%$ in women and because of the paucity of population studies measuring iron biomarkers (beyond hemoglobin $[\mathrm{Hb}])$ and complexities in their interpretation during inflammation, prevalence estimates of ID in low-income countries are uncertain. ${ }^{7}$

In Egypt, there is no reliable evidence or national registry about the prevalence of $H$. pylori infection or anemia in school children and, apart from individualized efforts, there are no national records about the scope of these two problems. Although there has been much research on low $\mathrm{Hb}$ concentrations and anemia worldwide, most of this has focused on children aged $<5$ years ( $0-59$ months) and pregnant women; data for school-age children are sparse. This study aimed to detect the prevalence of anemia including IDA and H. pylori infection in school-age children in Sharqia governorate in Egypt and the relationship between these two problems because it is essential to uncover the hidden causes of anemia to effectively control anemia in this country.

\section{Subjects and Methods}

Study Design, Population, and Sampling Techniques

We conducted this cross-sectional population-based study during the academic year 2017 to 2018 in primary schools in Sharqia governorate, Egypt. Sharqia governorate is the third most populous of the governorates of Egypt located in the northern part of the country. Its capital is the city of Zagazig. We listed all educational administrative departments at the Sharqia governorate. From the total educational administrative departments of Sharqia governorate, Zagazig educational administrative department was selected randomly by a lottery method then all primary schools located in Zagazig educational administrative department, including urban and rural areas, are listed from $\mathrm{A}$ to $\mathrm{Z}$ (from the first to the last one) and a random selection of 6 primary schools using a lottery method. All children from all grades in the six selected primary schools aged from 6 to 12 years were eligible for this study. According to local authority guidelines, regular yearly stool analysis for every student in primary school is done to detect parasitic infestations and regular deworming of school-age children in its control strategy. Regular deworming treatment reduces the intensity of infection and gives protection to those already infected. ${ }^{8}$

\section{Inclusion and Exclusion Criteria}

Following an initial screening, children with a history of H. pylori eradication or antacid use, ongoing iron therapy, liver disease or diabetes, with malformations or serious chronic diseases, inflammatory bowel disease or previous GI surgery, and ongoing parasitic infestations were excluded from the study. This study included a total of 1,200 students from all grades in the six selected primary schools, based on sample size calculation with Power Analysis and Sample Size Software.

\section{Data Collection}

All students that fulfilled the inclusion criteria were subjected to the following: medical history, clinical examination with special emphasis on manifestations of anemia (pallor, fatigue, irritability, palpitation, shortness of breath, pica, tachypnea, tachycardia, and koilonychia), and H. pylori infection (nausea, vomiting, loss of appetite, and chronic abdominal pain that was defined by the American Academy of Pediatrics' 2005 clinical report as long-lasting intermittent or constant abdominal pain that is functional or organic with a minimum duration of 3 months), ${ }^{9}$ and laboratory investigations included complete blood count (CBC) and $\mathrm{H}$. pylori antigen in stool. According to the level of $\mathrm{Hb}$, we divided the students into two groups: Anemic group with $\mathrm{Hb}$ level $<11.5 \mathrm{~g} / \mathrm{dL}$ and non-anemic group with $\mathrm{Hb}$ level $\geq 11.5 \mathrm{~g} / \mathrm{dL}$ based on the WHO definition of anemia published in 2011, ${ }^{10}$ and the serum ferritin level was done only for the anemic group as the best indicator for iron status. ${ }^{11,12}$

H. pylori antigen in stool is a noninvasive method with good sensitivity and specificity, $94 \%$ and $97 \%$ respectively in the global meta-analysis, in the diagnosis of $H$. pylori infection. ${ }^{13}$

\section{Specimen Collection and Processing}

Peripheral blood samples were collected and divided into two tubes: $1 \mathrm{~mL}$ on ethylenediamine tetraacetic acid tube for $\mathrm{CBC}$ and $1 \mathrm{~mL}$ on a heparinized tube; centrifuged plasma was separated and preserved at $=-20^{\circ} \mathrm{C}$ until the time of assay. Stool samples were preserved at $=-20^{\circ} \mathrm{C}$ until the time of 
the assay. The blood and stool samples collection staff included clinical nurses and laboratory technologists, under the supervision of general practitioners. $\mathrm{CBC}$ was performed by Sysmex cell counter kx-21 made in Japan. Serum ferritin was measured by using enzyme immunoassay for qualitative determination of ferritin in human plasma/serum (catalogue No.pt-ferr 96 manufactured by Pishtaz Teb Diagnostic-European authorized representative ID consulting services Ltd. Korbach, Germany). H. pylori antigen was performed by enzyme-linked immunosorbent assay for quantitative assay of $\mathrm{H}$. pylori $\mathrm{Ag}$ in human stool specimen using the kit manufactured by Immunospec Corporation (Canoga, California, United States) (reference catalogue No. E32-320 referred by European Authorized Representative: CE partner4U, the Netherlands).

\section{Ethical Consideration}

To start this study, written consent was obtained from the child's parents and the nature, and the aim of our study was explained to them. The study was approved by the ethical consideration committee in Institutional Review Board after taking the permission of local authorities.

\section{Statistical Analysis}

Data were collected and analyzed by SPSS version 20.0. Quantitative data were expressed as mean \pm standard deviation. Qualitative data were expressed as frequency and percentage. Independent-samples $t$-test of significance was used when comparing two means. Chi-squared $\left(\mathrm{X}^{2}\right)$ test of significance was used to compare proportions between two qualitative parameters. $p$-Value $\leq 0.05$ was considered significant while $p$-value $\leq 0.001$ was considered highly significant.

\section{Results}

A total of 1,200 students ( 620 boys and 580 girls) from six primary schools were enrolled in the study. The mean age of the children was $8.62 \pm 1.69$ years. H. pylori infection prevalence was $25 \%$ (300/1200). The mean $\mathrm{Hb}$ level was $12.79 \pm 1.15 \mathrm{~g} / \mathrm{dL}$ and the overall prevalence of anemia was $13.25 \%$. The microcytic hypochromic anemia accounted for $87.4 \%$ of the anemic group, and the mean ferritin level in the anemic group was $18.56 \pm 9.96 \mathrm{ng} / \mathrm{mL}$. The clinical manifestations related to anemia or $\mathrm{H}$. pylori infection were also shown in - Table 1.

In comparison with the nonanemic group, the anemic group had a significantly higher incidence of $H$. pylori infection diagnosed by stool antigen test, chronic abdominal pain, pallor, and a lower age $(p<0.001)$. However, regarding sex, no significant difference between anemic and nonanemic groups was observed. The prevalence of anemia among $H$. pylori-infected was 0.33 , and the prevalence of anemia among noninfected was 0.066 , so the prevalence ratio is 4.95. Based on this ratio, the proportion of children with anemia is 4.95 -fold greater if the child is infected with $H$. pylori (-Table 2).

The infected children showed a significantly higher incidence of pallor $(p<0.001)$ and recurrent abdominal pain
Table 1 Demographic and laboratory characteristics of all students enrolled in the study

\begin{tabular}{|c|c|c|}
\hline Variable & Frequency & Percent \\
\hline \multicolumn{3}{|l|}{ Age $(N=1200)$} \\
\hline $\begin{array}{l}<9 y \\
\geq 9 y\end{array}$ & $\begin{array}{l}608 \\
592\end{array}$ & $\begin{array}{l}50.7 \\
49.3\end{array}$ \\
\hline $\begin{array}{l}\text { Range } \\
\text { Mean } \pm \text { SD }\end{array}$ & \multicolumn{2}{|l|}{$\begin{array}{l}6-11.5 \\
8.62 \pm 1.69\end{array}$} \\
\hline \multicolumn{3}{|l|}{$\operatorname{Sex}(N=1200)$} \\
\hline $\begin{array}{l}\text { Males } \\
\text { Females }\end{array}$ & $\begin{array}{l}620 \\
580\end{array}$ & $\begin{array}{l}51.7 \\
48.3\end{array}$ \\
\hline \multicolumn{3}{|c|}{ H. pylori antigen in stool $(N=1200)$} \\
\hline $\begin{array}{l}\text { Infected children } \\
\text { Noninfected children }\end{array}$ & $\begin{array}{l}300 \\
900\end{array}$ & $\begin{array}{l}25 \\
75\end{array}$ \\
\hline \multicolumn{3}{|l|}{ Anemia $(N=1200)$} \\
\hline $\begin{array}{l}\text { Anemic group } \\
\text { Nonanemic group }\end{array}$ & $\begin{array}{l}159 \\
1041\end{array}$ & $\begin{array}{l}13.25 \\
86.75\end{array}$ \\
\hline \multicolumn{3}{|l|}{ Types of anemia $(N=159)$} \\
\hline $\begin{array}{l}\text { Microcytic hypochromic } \\
\text { Normocytic normochromic } \\
\text { Macrocytic }\end{array}$ & $\begin{array}{l}139 \\
3 \\
17\end{array}$ & $\begin{array}{l}87.4 \\
1.9 \\
10.7\end{array}$ \\
\hline \multicolumn{3}{|c|}{ Clinical manifestations $(N=1200)$} \\
\hline $\begin{array}{l}\text { Pallor } \\
\text { Chronic abdominal pain } \\
\text { No manifestations }\end{array}$ & $\begin{array}{l}292 \\
680 \\
228\end{array}$ & $\begin{array}{l}24.33 \\
56.7 \\
19.03\end{array}$ \\
\hline \multicolumn{3}{|l|}{$\mathrm{Hb} \mathrm{g} / \mathrm{dL}(N=1200)$} \\
\hline Mean \pm SD & $12.79 \pm 1.15$ & \\
\hline \multicolumn{3}{|c|}{ Ferritin level in the anemic group (ng/mL) } \\
\hline $\begin{array}{l}(n=159) \\
\text { Range } \\
\text { Mean } \pm S D\end{array}$ & $\begin{array}{l}4-33 \\
18.56 \pm 9.96\end{array}$ & \\
\hline
\end{tabular}

Abbreviation: SD, standard deviation.

$(p<0.05)$ and lower levels of $\mathrm{Hb}$, mean corpuscular volume (MCV), mean corpuscular hemoglobin (MCH), and hematocrit (HCT) in comparison with the non-infected children ( $p$ $<0.001$ ) (-Table 3).

In the anemic group, the mean ferritin level in $H$. pylori-infected children was $15.33 \pm 8.80 \mathrm{ng} / \mathrm{mL}$ and the mean level in the noninfected children was $20.51 \pm$ $10.15 \mathrm{ng} / \mathrm{mL}$, with a significant difference between $H$. pylori-infected and noninfected children $(p<0.001)$ (-Table 4).

In the infected children, the dominant type of anemia was microcytic hypochromic anemia, with a significantly higher incidence in comparison to other types of anemia $(p<0.001)$ (-Table 5).

\section{Discussion}

Various epidemiological studies conducted all over the world have shown an association between $H$. pylori infection and IDA. The association between $H$. pylori infection and the development of anemia, especially IDA, has been previously 
Table 2 Comparison between the two groups according to Helicobacter pylori infection and clinical characteristics of all students enrolled in the study $(n=1,200)$

\begin{tabular}{|c|c|c|c|c|c|c|}
\hline & & \multicolumn{2}{|l|}{ Groups } & \multirow[t]{2}{*}{ Total } & \multirow[t]{2}{*}{ Test } & \multirow[t]{2}{*}{$p$-Value } \\
\hline & & $\begin{array}{l}\text { Nonanemic group } \\
(n=1,041)\end{array}$ & $\begin{array}{l}\text { Anemic group } \\
(n=159)\end{array}$ & & & \\
\hline \multirow[t]{3}{*}{ Age $(y)$} & $<9 y$ & $481(46.2 \%)$ & 127 (79.9\%) & 608 (50.7\%) & \multirow[t]{2}{*}{$x^{2}=62.5$} & \multirow[t]{2}{*}{$<0.001^{a}$} \\
\hline & $\geq 9 y$ & $560(53.8 \%)$ & 32 (20.1\%) & 592 (49.3\%) & & \\
\hline & Mean \pm SD & $8.78 \pm 1.66$ & $7.35 \pm 1.33$ & $8.62 \pm 1.69$ & $\mathrm{t}=-10.3$ & $<0.001^{a}$ \\
\hline \multirow[t]{2}{*}{ Sex } & Male & $549(52.7 \%)$ & $77(48.4 \%)$ & $626(52.2 \%)$ & \multirow[t]{2}{*}{$x^{2}=1.02$} & \multirow[t]{2}{*}{ NS } \\
\hline & Female & 492 (47.3\%) & $82(51.6 \%)$ & $574(47.8 \%)$ & & \\
\hline \multirow{2}{*}{$\begin{array}{l}\text { H. pylori } \\
\text { antigen in stool }\end{array}$} & Noninfected children & $840(80.6 \%)$ & $60(37.7 \%)$ & $900(75 \%)$ & \multirow[t]{2}{*}{$x^{2}=137.8$} & \multirow[t]{2}{*}{$<0.001^{a}$} \\
\hline & Infected children & 201 (19.4\%) & 99 (62.3\%) & $300(25 \%)$ & & \\
\hline \multirow{2}{*}{$\begin{array}{l}\text { Chronic } \\
\text { abdominal pain }\end{array}$} & No & 477 (45.8\%) & $43(27.0 \%)$ & $520(43.3 \%)$ & \multirow[t]{2}{*}{$x^{2}=19.8$} & \multirow[t]{2}{*}{$<0.001^{a}$} \\
\hline & Yes & $564(54.2 \%)$ & $116(73.0 \%)$ & $680(56.7 \%)$ & & \\
\hline \multirow[t]{2}{*}{ Pallor } & No & $868(83.4 \%)$ & $40(25.2 \%)$ & $908(75.7 \%)$ & \multirow[t]{2}{*}{$x^{2}=253.9$} & \multirow[t]{2}{*}{$<0.001^{c}$} \\
\hline & Yes & $173(16.6 \%)$ & $119(74.8 \%)$ & $292(24.3 \%)$ & & \\
\hline
\end{tabular}

Abbreviation: SD, standard deviation.

aStatistically highly significant difference $(p \leq 0.001)$, NS; not significant.

Note: $\mathrm{X}^{2}$; Chi-squared test, $\mathrm{t}$; Student's t-test.

Table 3 Comparison between Helicobacter pylori-infected and noninfected children regarding laboratory and clinical parameters $(n=1,200)$

\begin{tabular}{|c|c|c|c|c|c|}
\hline \multicolumn{2}{|c|}{$\mathrm{CBC}$ and clinical parameters } & \multicolumn{2}{|l|}{ H. pylori infection } & \multirow{2}{*}{$\begin{array}{l}\text { Test } \\
t=-8.4\end{array}$} & \multirow{2}{*}{$\begin{array}{l}p \text {-Value } \\
<0.001^{\text {b }} \\
\end{array}$} \\
\hline $\mathrm{Hb}$ & Mean \pm SD & $\begin{array}{l}\text { Infected }(n=300) \\
12.24 \pm 1.11\end{array}$ & $\begin{array}{l}\text { Noninfected }(\boldsymbol{n}=900) \\
12.66 \pm 0.59\end{array}$ & & \\
\hline $\mathrm{MCH}$ & Mean \pm SD & $24.25 \pm 3.22$ & $25.51 \pm 2.21$ & $t=-7.4$ & $<0.001^{b}$ \\
\hline MCV & Mean \pm SD & $77.39 \pm 9.10$ & $78.99 \pm 5.79$ & $t=-3.5$ & $<0.001^{\mathrm{b}}$ \\
\hline $\mathrm{HCT}$ & Mean \pm SD & $33.9 \pm 1.52$ & $39.2 \pm 2.12$ & $t=30.14$ & $<0.001^{\mathrm{b}}$ \\
\hline Pallor & $\begin{array}{l}\text { No } \\
\text { Yes }\end{array}$ & $\begin{array}{l}180(60 \%) \\
120(40 \%) \\
\end{array}$ & $\begin{array}{l}724(80.5 \%) \\
176(19.5 \%) \\
\end{array}$ & $X^{2}=47.8$ & $<0.001^{\mathrm{b}}$ \\
\hline Chronic abdominal pain & $\begin{array}{l}\text { No } \\
\text { Yes }\end{array}$ & $\begin{array}{l}110(36.6 \%) \\
190(63.4 \%)\end{array}$ & $\begin{array}{l}409(45.4 \%) \\
491(54.6 \%)\end{array}$ & $x^{2}=7.3$ & $<0.05^{\mathrm{a}}$ \\
\hline
\end{tabular}

Abbreviations: CBC, complete blood count; $\mathrm{Hb}$, hemoglobin; $\mathrm{HCT}$, hematocrit; $\mathrm{MCH}$, mean corpuscular hemoglobin; MCV, mean corpuscular volume; SD, standard deviation.

aStatistically significant difference $(p \leq 0.05)$.

bStatistically highly significant difference $(p \leq 0.001)$.

Note: $X^{2}$, Chi-squared test; $t$, Student's $t$-test.

Table 4 Comparison between Helicobacter pylori-infected and noninfected children regarding the ferritin level in the anemic group $(n=159)$

\begin{tabular}{|c|c|c|c|c|}
\hline & \multicolumn{2}{|l|}{ H. pylori infection } & \multirow[t]{2}{*}{$t$} & \multirow[t]{2}{*}{$p$-Value } \\
\hline & Infected $(n=99)$ & Noninfected $(n=60)$ & & \\
\hline $\begin{array}{l}\text { Ferritin level in the anemic group }(\mathrm{ng} / \mathrm{mL}) \\
(n=159) \\
\text { Mean } \pm \text { SD }\end{array}$ & $15.33 \pm 8.800$ & $20.51 \pm 10.15$ & 3.2 & $<0.001^{\mathrm{a}}$ \\
\hline
\end{tabular}

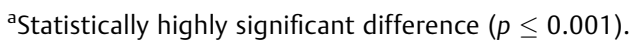

Note: $t$ refers to Student's t-test. 
Table 5 Types of anemia in Helicobacter pylori-infected children $(n=99)$

\begin{tabular}{|l|l|l|l|l|}
\hline $\begin{array}{l}\text { Types of anemia in } \\
\begin{array}{l}\text { H. pylori-infected } \\
\text { children }(\boldsymbol{n}=99)\end{array}\end{array}$ & $\boldsymbol{n}$ & $\%$ & $\mathrm{X}^{2}$ & -Value \\
\cline { 1 - 3 } Microcytic hypochromic & 87 & 87.9 & 133.4 & $<0.001^{\mathrm{a}}$ \\
\cline { 1 - 3 } Normocytic normochromic & 3 & 3 & & \\
\cline { 1 - 4 } Macrocytic & 9 & 9.1 & & \\
\hline
\end{tabular}

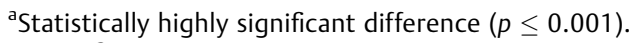

Note: $\mathrm{X}^{2}$ refers to Chi-squared test.

studied and until now it is still a matter of argument. Consequently, new programs designed to decrease the prevalence of ID and IDA in high-risk groups may necessitate eradicating $H$. pylori infection. ${ }^{14}$

H. pylori colonization of the stomach persists in some individuals for a long time and is closely related to gastritis, duodenal ulcers, and extra-GI disorders, including IDA, in childhood. ${ }^{15}$ ID is common in all populations, but particularly devastating for pregnant women, young children, and those with the greatest requirements. ID is associated with increased vulnerability to infections and permanent cognitive impairment, particularly among school-age children. IDA negatively affects cognitive functions and psychomotor development. ${ }^{16}$

The prevalence of anemia and $H$. pylori infection is unequally distributed among different populations; so, in this study, we aimed to evaluate the prevalence of $H$. pylori infection and anemia among school children and to evaluate the association between $H$. pylori infection and anemia. The results of this study revealed that the overall prevalence of $H$. pylori infection was $25 \%$. This finding was consistent with the findings of Zamani et al ${ }^{17}$ who found a prevalence of $H$. pylori infection in $26 \%$ of Iranian primary school children and Naous et al ${ }^{18}$ who found a prevalence of $H$. pylori infection of $21 \%$ in asymptomatic Lebanese pediatric patients. Furthermore, in a study conducted in Turkey between 2013 and 2014 with 2 to 18 -year-old children, the $H$. pylori infection prevalence rate was $30.7 \%{ }^{19}$ This was consistent with the epidemiological studies in Poland, which evaluated $H$. pylori seroprevalence and reported that $32.0 \%$ of children below 18 years of age were infected. ${ }^{20}$

In contrast to findings of this study, a higher prevalence of $H$. pylori infection among Egyptian children was reported in studies conducted by Galal et al, Deeb et al, Abdulqawi et al, and Mohammad et al $(64.6,44,68$, and $72.4 \%$, respectively). ${ }^{21-24}$

Our finding in terms of the prevalence of H. pylori infection was not consistent with a study conducted by Hasosah et $\mathrm{al}^{25}$ who reported that the prevalence of $H$. pylori infection among symptomatic children in Saudi Arabia was 49.8\%. According to Iwańczak et al, ${ }^{26}$ there was a higher prevalence of $H$. pylori infection in Ethiopian children (48\%), Nigeria (82\%), Mexico (43\%), and Bulgaria (61.7\%).

On the other hand, many studies reported a lower prevalence of $H$. pylori infection in sub-Saharan Africa (14.2\%), Iran
(13.1\%), the United States (7.5\%), Italy (8.7\%), Japan (1.8\%), Australia (15.5\%), Canada (7.1\%), the Netherlands (1.2\%), and Sweden (3-13.6\%). ${ }^{22,26-28}$

This variability in $H$. pylori infection rates between different studies is due to differences in the study design, geographic areas, target population, population inclusion, exclusion criteria, sample size, and $H$. pylori detection methods. ${ }^{13}$

The relatively low prevalence of $H$. pylori infection in this study could be due to $H$. pylori detection methods, as antibody testing procedures for $\mathrm{H}$. pylori detection are used in some studies that lead to false high results and do not differentiate between past or active infection. Our study employed an H. pylori stool antigen testing method because of its noninvasive nature and effectiveness especially in children. Spontaneous $H$. pylori infection clearance has been observed due to exposure to antibiotics to treat other infections in childhood, the period during which antibiotics are widely used, and spontaneous eradication has been associated with several variables and has been reported to be higher in children receiving iron supplements for ID. $^{13,28-30}$

The relatively low prevalence of $H$. pylori infection in this study could be also due to the autocurability and the reinfection phenomena, as Zhou et $\mathrm{al}^{28}$ have documented that the annual autocurability rate was $2.9 \%$ among the pediatric population.

With regard to Hb level in this study, we did not anticipate these results, including the mean $\mathrm{Hb}$ level $(12.79 \pm 1.15$ $\mathrm{gm} / \mathrm{dL}$ ) and the prevalence of anemia (13.25\%), and the microcytic anemia accounted for $87.4 \%$ of the anemic group. The prevalence of anemia among school children in this study was comparable with the results of other similar studies among school children in Indonesia (13\%), ${ }^{31}$ Addis Ababa (the capital city of Ethiopia) (15.5\%), ${ }^{32}$ and Turkey (15.7\%). ${ }^{33}$ In China, a significant decrease in the prevalence of anemia was observed from $12.6 \%$ in 2002 to $6.6 \%$ in 2010 to 2012. ${ }^{34}$

In contrast to our study results, higher trends have been described in population-based studies among young children in Egypt that reported a higher prevalence of anemia like Mansour et $\mathrm{al}^{35}$ who stated that $53.1 \%$ of the school children were anemic and a survey conducted by Salama and Labib, earlier in three Egyptian governorates (Fayoum, Beni Suef, and Minia), reported that the prevalence of anemia was 59.3\%. ${ }^{36}$ Also, other studies conducted among Egyptian school children reported that the prevalence of anemia was 38.7 and $39.9 \% \%^{1,37}$ The global anemia prevalence was $47.4 \%$ in preschool-age children and $\sim 25 \%$ of school-age children as reported by Gonete et al (25.5\%), ${ }^{38}$ Ngui et al $(26.2 \%),{ }^{39}$ and Oliveira et al (21.6\%). ${ }^{40}$

Based on the WHO report, anemia affects 45.7 to $49.1 \%$ of school-age children in the world, and the prevalence of anemia among school-age children in Africa ranged from 64.3 to $71 \%{ }^{41}$

Contrary to expectations, our findings indicated lower anemia prevalence in school-age children, and this can be explained in many ways, including the exclusion criteria of 
our study: any child with a history of liver disease or diabetes, with malformations or serious chronic diseases, inflammatory bowel disease or previous GI surgery, and parasitic infestations. The Hb concentration cutoff for anemia definition in this study was relatively high $(11.5 \mathrm{~g} / \mathrm{dL})$ in comparison to other studies that reported $\mathrm{Hb}$ concentration cutoff was 10 to $11.5 \mathrm{~g} / \mathrm{dL}$.

Another reason for a relatively low anemia prevalence in school-age children in this study is the national program of iron supplementation in our country that was implemented before the study and the mass media for increasing knowledge about the danger of anemia and lastly, the efforts done by the ministry of health in Egypt for early detection of anemia in early life as all infants are examined for $\mathrm{Hb}$ level at the age of 1 year during the routine scheduled examination and vaccination program. The American Academy of Pediatrics suggests a routine screening for IDA for all children at the age of 12 months by using $\mathrm{Hb}$ concentration. ${ }^{42}$

In 2008, the Egyptian government began implementation of a 5-year national program to fortify the wheat flour used in baking subsidized baladi bread with iron and folic acid. ${ }^{43}$ The WHO author panel reported that $7.1 \mathrm{mg} /$ day of ferrous sulfate fortification of flour is moderately effective, whereas 11 $\mathrm{mg} /$ day is highly effective. The Egyptian program corresponds to this highly effective category, and it is predicted by the panel that a highly effective program might reduce ID prevalence in at-risk populations to levels seen in industrialized countries. Many campaigns have used iron supplements, especially in schools, to combat ID and malnutrition. ${ }^{44}$

The mean ferritin level in this study in the anemic group was $18.56 \pm 9.96 \mathrm{ng} / \mathrm{mL}$. Furthermore, less than $15 \mu \mathrm{g} / \mathrm{L}$ ferritin is specific for ID, whereas less than $30 \mu \mathrm{g} / \mathrm{L}$ ferritin is highly suggestive (lower ferritin thresholds for ID diagnosis in children: $<10-12 \mathrm{ng} / \mathrm{mL}$ ) but when inflammation exists, the WHO defines ID at a ferritin level less than 30 $\mu \mathrm{g} / \mathrm{L}$ in children under 5 years and less than $70 \mu \mathrm{g} / \mathrm{L}$ in older children. The WHO estimates that $50 \%$ of anemic cases worldwide are due to ID. ${ }^{45}$

There was no significant difference between anemic and nonanemic groups regarding sex in this study with no plausible explanation and this came in agreement with other studies that have shown no significant difference in the mean $\mathrm{Hb}$ concentration between boys and girls. ${ }^{46-49}$ However, other studies have shown that the mean $\mathrm{Hb}$ concentration is generally higher in boys than girls. ${ }^{50,51}$

Microcytic hypochromic anemia accounted for $87.4 \%$ of the anemic group in this study. Similarly, Maiti et $\mathrm{l}^{52}$ stated that microcytic hypochromic anemia was the most prevalent (71.3\%) morphologic type of anemia in children, and other studies reveal incidence varying between 45 and 70\%. ${ }^{53,54}$

Our studied groups followed the normal distribution curve regarding the age and there is a marked significant difference between anemic and nonanemic children regarding the age with $79.9 \%$ of anemic children who were below 9 years old; so the prevalence of anemia is much higher in the first three grades in primary school children and this may be explained by feeding habits of Egyptian families that contain more cereals and fewer iron supplementations affecting more the lower ages, who did not follow the correct feeding programs after school entrance.

In the anemic group, this study revealed that the mean ferritin level in $H$. pylori-infected children was significantly lower than the mean level in the noninfected children. Furthermore, the anemic group had a significantly higher incidence of $H$. pylori infection in comparison with the nonanemic group, so there was an association between infection with $H$. pylori and not only the development of anemia but also iron status in the body.

These study findings, in terms of the significance of association between $H$. pylori infection and anemia in school-age children, were consistent with a study conducted by Mourad-Baars et $\mathrm{al}^{55}$ who reported a significant association between $H$. pylori and IDA in children, and the treatment of $H$. pylori infection showed an increase in $\mathrm{Hb}$ level in 65\% children without iron supplementation. So, $H$. pylori eradication therapy combined with iron administration showed an increase in $\mathrm{Hb}$ level in $75 \%$ children that is more effective than iron administration alone for the treatment of IDA.

Similarly, Hassan et $\mathrm{al}^{56}$ revealed that there was a significant increase in the number of positive samples for $H$. pylori antigen in stool among anemic versus nonanemic controls and a significant association between children with IDA and positive $H$. pylori infection in school-age children. Baggett et $\mathrm{al}^{57}$ suggested that infection with $H$. pylori may contribute to ID and IDA among children in countries where these conditions are highly prevalent.

A recent systematic review reported that, in observational studies, compared with uninfected persons, $H$. pylori-infected individuals are at greater risk for ID and IDA, and clinical trials have shown that combined treatment of $H$. pylori eradication and iron supplementation results in a larger serum ferritin increase than iron supplementation alone. ${ }^{58}$

In contrast to this study's results, Zahmatkeshan et $\mathrm{al}^{59}$ and Sarker et $\mathrm{al}^{60}$ reported no correlation between IDA and $H$. pylori infection in school-age children in Iran and Bangladesh, respectively. In addition, a few studies reported no significant association between serum ferritin level or IDA and antibody titer against $H$. pylori bacteria in school-age children. ${ }^{17,61,62}$

In this study, there was a statistically highly significant difference between anemic and nonanemic groups with regard to chronic abdominal pain and pallor. At the same time, there was a statistically highly significant difference between $H$. pylori-infected and noninfected groups with regard to pallor and a statistically significant difference regarding chronic abdominal pain. Consequently, a coincidence of pallor as a manifestation of anemia with recurrent abdominal pain as a manifestation of $H$. pylori infection may highlight the need for studying the relationship between anemia and $H$. pylori infection as causation not only an association.

Hassan et $\mathrm{al}^{56}$ found an association between $H$. pylori infection and GI disorders such as recurrent abdominal pain. In our study results, dyspepsia, chronic gastritis, and peptic ulcers were associated with $H$. pylori infection and suggested that $H$. pylori infection is more frequently associated with gastritis than with peptic ulcer disease in children. H. pylori 
gastritis is a cause of recurrent abdominal pain syndrome in children.

Concerning CBC parameters ( $\mathrm{Hb}, \mathrm{MCV}, \mathrm{MCH}, \mathrm{HCT}$ ), there was a statistically highly significant difference between $H$. pylori-infected and noninfected groups and there was a statistically highly significant difference between types of anemia. Microcytic hypochromic anemia is the most common type $(87.9 \%)$ in $H$. pylori-infected group in this study. This was consistent with El-Kady et al $^{63}$ who reported that H. pylori infection significantly affected the Hb level, MCV, $\mathrm{MCH}$, and red blood cells distribution width in studied cases. Meanwhile, $H$. pylori infection significantly affected the serum iron, serum ferritin, and total iron-binding capacity (TIBC) in studied cases of IDA.

Similarly, several studies highlighted that after confirmation of eradication of $H$. pylori, the mean values of $\mathrm{Hb}$ and iron indices including ferritin have improved significantly without the use of iron supplementation that indicates improved absorption of dietary iron with subsequent improvement in IDA. $^{64,65}$

Many studies showed a significant reduction was observed in the levels of serum $\mathrm{Hb}$, iron, and ferritin among infected children with $H$. pylori compared with noninfected ones as this study proved. ${ }^{66-69}$

In contrast to these study results, Soylu and Ozturk ${ }^{70}$ conducted a study in Imam Reza Hospital of Mashad on 184 patients. No significant difference was detected between the average serum ferritin level of the $H$. pylori infected group and control group. Also, Sh and Al-Ani ${ }^{71}$ stated that there was no significance between $H$. pylori infection and age, weight, height, platelets, red blood cells, $\mathrm{Hb}, \mathrm{MCV}, \mathrm{MCH}$, ferritin, and iron. Haghi-Ashtiani et al $^{72}$ found no relationship between H. pylori infection and IDA. However, Hoseinzadeh et $\mathrm{al}^{73}$ found a significant negative correlation of $H$. pylori antibody level with serum iron and ferritin and its positive correlation with TIBC levels.

The causes of ID and/or low iron absorption during H. pylori infection have been attributed to several mechanisms, such as microbleeding and/or iron uptake affection, which may deplete iron stores in patients even without ulcer disease. Also, H. pylori requires iron for its growth; it expresses proteins associated with iron metabolism and decrease in mucosal iron absorption capacity due to reduced gastric acid output, competition of the bacterium with the host for the dietary iron supply, reduction in the gastric juice vitamin $\mathrm{C}$ content in infected subjects, increased hepcidin production from hepatocytes in response to IL-6 production associated with $H$. pylori gastritis, or sequestration of iron in lactoferrin in the gastric mucosa. Consequently, $H$. pylori-positive subjects before treatment had a smaller increase in serum iron compared with $H$. pylori-negative subjects, and after $H$. pylori eradication in the $H$. pylori-positive subjects, their serum iron increase was similar to those of noninfected subjects, suggesting that H. pylori infection impairs oral iron uptake as in Hassan et $\mathrm{al}^{56}$ and Chiu et $\mathrm{al}^{74}$ studies.

Regarding the presence of macrocytic anemia in $H$. pylori-infected children, Gravina et $\mathrm{al}^{75}$ stated that decreased absorption of vitamin B12 in the case of $H$. pylori infection might be due to intrinsic factor deficiency, which is damaged in the case of $H$. pylori-related corpus-predominant gastritis and several meta-analyses clearly showed a strong association between $H$. pylori infection and IDA. According to tertiary referral hospital laboratory results, the vitamin B12 levels in patients with macrocytic anemia in our study were low that necessitate treatment with vitamin B12 and treatment of associated $H$. pylori infections. In addition, a correlation between $H$. pylori infection and low serum levels of vitamin B12, which increased after $H$. pylori eradication, may be another reason for anemia caused by H. pylori. $^{76}$

The study had strength points including that such information about anemia and $H$. pylori infection is of greatest importance to public health authorities before any action regarding these problems can be undertaken. Based on the prevalence of $H$. pylori infection and anemia, it is recommended that screening and treatment programs for $H$. pylori among anemic children in socially deprived areas be considered as a way forward in tackling these problems.

Due to methodological issues, our study has limitations that we measured serum ferritin level in the anemic children only and did not investigate for subclinical inflammation or infection that leads to elevation of serum ferritin levels, exclusion criteria of the study, and this may lead to underestimation of the proportion of anemic children with ID. The cross-sectional design of this study limits inference about the causal relationship between $H$. pylori infection and anemia. Furthermore, the association between anemia and $H$. pylori infection raises concerns about confounding by unmeasured exposures. Additionally, the $H$. pylori stool antigen could not be compared with a gold standard test to diagnose $H$. pylori infection. Finally, our study was conducted in a single city, which may limit the generalizability of our findings.

Considering the results of this study, it is recommended to prioritize the development of diagnostic methods and treatments for $H$. pylori in Egypt. We should carefully consider appropriate interventions to eradicate $H$. pylori, to improve anemia status. In children with unexplained IDA, $H$. pylori testing and treatment may be clinically indicated and a combination of $H$. pylori eradication therapy and iron therapy may increase ferritin and $\mathrm{Hb}$ levels. We should screen high-risk children with pallor and abdominal pain using $H$. pylori stool antigen, $\mathrm{CBC}$, and ferritin to identify those children for which treatment of $H$. pylori and IDA would lead to reduce the prevalence and associated short- and longterm consequences.

\section{Conclusion}

According to this study, H. pylori infection was found in $25 \%$ of school-age children, and anemia was reported in $13.25 \%$ of them, with microcytic hypochromic anemia being the most common type. The results of this study demonstrate also a significant association between $H$. pylori infection and anemia including IDA in school-age children as the prevalence of 
H. pylori infection was higher among anemic children when compared with nonanemic.

\section{Authors' Contributions}

M.A., T.A.A., and E.G.B. designed the study, collected, and interpreted data, and wrote the manuscript. M.A., T.A.A., E.G.B., and D.H. collected, evaluated the patient's interpreted data, and wrote the manuscript. All the authors evaluated the patient's interpreted data and wrote the manuscript. All the authors critically contributed to the discussion and data interpretation, reviewed, and approved the final manuscript.

\section{Funding}

None.

\section{Conflict of Interest}

None declared.

\section{Acknowledgment}

We would like to thank patients' families for their willingness to take part in this study.

\section{References}

1 Aref MI, Khalifa HO. Prevalence of anemia and associated factors among school-age children in al-haram zone, Giza governorate, Egypt. Azhar Med J 2019;48(02):165-176

2 Mattiello V, Schmugge M, Hengartner H, von der Weid N, Renella RSPOG Pediatric Hematology Working Group. Diagnosis and management of iron deficiency in children with or without anemia: consensus recommendations of the SPOG Pediatric Hematology Working Group. Eur J Pediatr 2020;179(04):527-545

3 Tiwari S, Aggarwal S, Kaushik S, Kumar S. Iron deficiency anemia. J Assoc Physicians India 2020;68(01):101-112

4 Stevens GA, Finucane MM, De-Regil LM, et al; Nutrition Impact Model Study Group (Anaemia) Global, regional, and national trends in haemoglobin concentration and prevalence of total and severe anaemia in children and pregnant and non-pregnant women for 1995-2011: a systematic analysis of populationrepresentative data. Lancet Glob Health 2013;1(01):e16-e25

5 Franceschi F, Annalisa T, Teresa DR, et al. Role of Helicobacter pylori infection on nutrition and metabolism. World J Gastroenterol 2014;20(36):12809-12817

6 Gheibi Sh, Farrokh-Eslamlou HR, Noroozi M, Pakniyat A. Refractory iron deficiency anemia and Helicobacter pylori infection in pediatrics: a review. Iran J Ped Hematol Oncol 2015;5(01):50-64

7 Pasricha SR, Tye-Din J, Muckenthaler MU, Swinkels DW. Iron deficiency. Lancet 2020

8 Rayan P, Verghese S, McDonnell PA. Geographical location and age affects the incidence of parasitic infestations in school children. Indian J Pathol Microbiol 2010;53(03):498-502

9 DiLorenzo C, Colletti RB, Lehmann HP, Boyle JT, Gerson WT, Hyams JS. Technical report: chronic abdominal pain in children. J Pediatr Gastroenterol Nutr 2005;40(03):249-261

10 WHO. The Global Prevalence of Anaemia in 2011. Geneva: World Health Organization; 2015

11 Musallam KM, Taher AT. Iron deficiency beyond erythropoiesis: should we be concerned? Curr Med Res Opin 2018;34(01):81-93

12 Polin V, Coriat R, Perkins G, et al. Iron deficiency: from diagnosis to treatment. Dig Liver Dis 2013;45(10):803-809

13 Wang YK, Kuo FC, Liu CJ, et al. Diagnosis of Helicobacter pylori infection: current options and developments. World J Gastroenterol 2015;21(40):11221-11235
14 Kiran U, Kumar V. Etiology of anemia, iron deficiency among young children and strategies to overcome. Int J Physiol 2020;8 (02):171-176

15 Kato S, Shimizu T, Toyoda S, et al; Japanese Society for Pediatric Gastroenterology, Hepatology and Nutrition. The updated JSPGHAN guidelines for the management of Helicobacter pylori infection in childhood. Pediatr Int (Roma) 2020;62(12): 1315-1331

16 Pivina L, Semenova Y, Doşa MD, Dauletyarova M, Bjørklund G. Iron deficiency, cognitive functions, and neurobehavioral disorders in children. J Mol Neurosci 2019;68(01):1-10

17 Zamani A, Shariat M, Oloomi Yazdi Z, Bahremand S, Akbari Asbagh P, Dejakam A. Relationship between Helicobacter pylori infection and serum ferritin level in primary school children in Tehran-Iran. Acta Med Iran 2011;49(05):314-318

18 Naous A, Al-Tannir M, Naja Z, Ziade F, El-Rajab M. Fecoprevalence and determinants of Helicobacter pylori infection among asymptomatic children in Lebanon. J Med Liban 2007;55(03):138-144

19 Ali B, Chloë W, Mehmet A, et al. Presence of gastric Helicobacter species in children suffering from gastric disorders in Southern Turkey. Helicobacter 2018;23(05):e12511

20 Łaszewicz W, Iwańczak F, Iwańczak BTask Force of the Polish Society of Gastroenterology Task Force of the Polish Society of Gastroenterology. Seroprevalence of Helicobacter pylori infection in Polish children and adults depending on socioeconomic status and living conditions. Adv Med Sci 2014;59(01):147-150

21 Galal YS, Ghobrial CM, Labib JR, Abou-Zekri ME. Helicobacter pylori among symptomatic Egyptian children: prevalence, risk factors, and effect on growth. J Egypt Public Health Assoc 2019;94 (01):17

22 Deeb MM, Bahbah WA, Abou-Elela DH, Hessen MM. Seroprevalence of Helicobacter pylori infection among school children in $\mathrm{Al}$ Qulubia governorate. Menoufia Med J 2018;31(03):963

23 Abdulqawi K, El-Mahalaway AM, Abdelhameed A, Abdelwahab AA. Correlation of serum antibody titres with invasive methods for rapid detection of Helicobacter pylori infections in symptomatic children. Int J Exp Pathol 2012;93(04):295-304

24 Mohammad MA, Hussein L, Coward A, Jackson SJ. Prevalence of Helicobacter pylori infection among Egyptian children: impact of social background and effect on growth. Public Health Nutr 2008; 11(03):230-236

25 Hasosah M, Satti M, Shehzad A, et al. Prevalence and risk factors of Helicobacter pylori infection in Saudi children: a three-year prospective controlled study. Helicobacter 2015;20(01):56-63

26 Iwańczak BM, Buchner AM, Iwańczak F. Clinical differences of Helicobacter pylori infection in children. Adv Clin Exp Med 2017; 26(07):1131-1136

27 Awuku YA, Simpong DL, Alhassan IK, Tuoyire DA, Afaa T, Adu P. Prevalence of helicobacter pylori infection among children living in a rural setting in Sub-Saharan Africa. BMC Public Health 2017; 17(01):360. Doi: 10.1186/s12889-017-4274-Z

28 Zhou Y, Ye Z, Huang J, Huang Y, Yan W, Zhang Y. High prevalence and low spontaneous eradication rate of Helicobacter pylori infection among schoolchildren aged 7-12 years. Acta Paediatr 2018;107(09):1624-1628

29 da Silva Roque IJR, Machado RS II, Rodrigues D III, Rech P IV, Kawakami VE. Prevalence of Helicobacter pylori infection in an indigenous community in São Paulo and associated factors: crosssectional study. JUNTOS PARA TRANSFORMAR. 2017;135(02): 140-145

30 Duque X, Vilchis J, Mera R, et al. Natural history of Helicobacter pylori infection in Mexican schoolchildren: incidence and spontaneous clearance. J Pediatr Gastroenterol Nutr 2012;55(02): 209-216

31 Andriastuti M, Ilmana G, Nawangwulan SA, Kosasih KA. Prevalence of anemia and iron profile among children and adolescent with low socio-economic status. Int J Pediatr Adolesc Med 2020;7 (02):88-92 
32 Getaneh Z, Enawgaw B, Engidaye G, et al. Prevalence of anemia and associated factors among school children in Gondar town public primary schools, northwest Ethiopia: a school-based cross-sectional study. PLoS One 2017;12(12):e0190151. Doi: 10.1371/journal.pone.0190151

33 Pektaş E, Aral YZ, Yenisey Ç The prevalence of anemia and nutritional anemia in primary school children in the City of Aydın. Meandros Med J 2015;16:97-107

$34 \mathrm{Wu}$ J, Hu Y, Li M, et al. Prevalence of anemia in Chinese children and adolescents and its associated factors. Int J Environ Res Public Health 2019;16(08):1416. Doi: 10.3390/ijerph16081416

35 Mansour RE, Abu Zeid A, Bahaa El Din RM. Cross sectional study to assess Malnutrition and associated risk factors among primary school children in Kafr Sakr, Sharqia, Egypt. Zagazig Univ Med J 2020;26(05):725-734

36 Salama RA, Labib MR. The prevalence of anemia among informal primary school children: a community based study in Rural Upper Egypt. Epidemiol Biostat Public Health 2016;13(01):

37 Suzan M, Salah M, Aliaa M, Hasnaa A. Iron deficiency and iron deficiency anemia in adolescent girls in Rural Upper Egypt. Int Blood Res Rev 2016;5(04):1-6

38 Gonete KA, Tariku A, Wami SD, Derso T. Prevalence and associated factors of anemia among adolescent girls attending high schools in Dembia District, Northwest Ethiopia, 2017. Arch Public Health 2018;76:79

39 Ngui R, Ravindran S, Ong DB, et al. Intestinal parasitic infections and the level of immunosuppression in HIV seropositive individuals with diarrhoea in Kilimanjaro, Tanzania: a cross-sectional study. PLoS Negl Trop Dis 2013;18(03):122-139

40 Oliveira D, Ferreira FS, Atouguia J, Fortes F, Guerra A, CentenoLima S. Infection by intestinal parasites, stunting and anemia in school-aged children from Southern Angola. PLoS One 2015;10 (09): 0137327

41 Benoist BD, McLean E, Egll I, Cogswell M. Worldwide Prevalence of Anaemia 1993-2005: WHO Global Database on Anaemia. Geneva: WHO Global Database on Anaemia; 2008

42 Baker RD, Greer FRCommittee on Nutrition American Academy of Pediatrics. Diagnosis and prevention of iron deficiency and irondeficiency anemia in infants and young children (0-3 years of age). Pediatrics 2010;126(05):1040-1050

43 Elhakim N, Laillou A, El Nakeeb A, Yacoub R, Shehata M. Fortifying baladi bread in Egypt: reaching more than 50 million people through the subsidy program. Food Nutr Bull 2012;33(4, Suppl):S260-S271

44 Hurrell R, Ranum P, de Pee $S$, et al. Revised recommendations for iron fortification of wheat flour and an evaluation of the expected impact of current national wheat flour fortification programs. Food Nutr Bull 2010;31(1, Suppl):S7-S21

45 World Health Organization. Serum Ferritin Concentrations for the Assessment of Iron Status and Iron Deficiency in Populations. Geneva: World Health Organization; 2011

46 Mohamed E, Ahmed O, Youssef A. Iron deficiency and anemia in rural school children in a coastal area of Morocco. Pak J Nutr 2008; 7:400-403

47 Abdel-Rasoul GM, El Bahnasy RE, El Shazly HM, Gabr HM, AbdelAaty NB. Epidemiology of iron-deficiency anemia among primary school children (6-11 years), Menoufia governorate, Egypt. Menoufia Med J 2015;28(03):663

48 Achouri I, Aboussaleh Y, Sbaibi R, Ahami A, El Hioui M. Prevalence of iron deficiency anaemia among school children in Kenitra. Pak J Biol Sci 2015;18(04):191-195

49 Le Nguyen BK, Le Thi H, Nguyen Do VA, et al. Double burden of undernutrition and overnutrition in Vietnam in 2011: results of the SEANUTS study in 0.5-11-year-old children. Br J Nutr 2013; 110:S45-S56

50 Li L, Luo R, Medina A, Rozelle S. The prevalence of anemia in central and eastern China: evidence from the China health and nutrition survey. Southeast Asian J Trop Med Public Health 2015; 46(02):306-321
51 Egbi G, Steiner-Asiedu M, Kwesi FS, et al. Anaemia among school children older than five years in the Volta Region of Ghana. Pan Afr Med J 2014;17(Suppl 1):10

52 Maiti D, Acharya S, Basu S. Recognizing missed opportunities to diagnose and treat iron deficiency anemia: a study based on prevalence of anemia among children in a teaching hospital. J Family Med Prim Care 2019;8(03):899-903

53 Sahana KS, Ghaliyah K, Anitha P, Prakash S. A study of anemia in hospitalised infants at a tertiary care hospital. Natl J Community Med 2015;6:22-27

54 Manohar Reddy CV, Sai Geeta C. Evaluation of anemia in hospitalised infants at a tertiary care hospital. Int J Med Res Prof. 2017; 3:208-210

55 Mourad-Baars PE, Verspaget HW, Mertens BJ, Mearin ML. Low prevalence of Helicobacter pylori infection in young children in the Netherlands. Eur J Gastroenterol Hepatol 2007;19(03): 213-216

56 Hassan MA, Kasem IA, Ali AS. Correlation between Helicobacter pylori infection and iron deficiency anemia in school-aged children. Egypt J Hosp Med 2020;81(02):1489-1498

57 Baggett HC, Parkinson AJ, Muth PT, Gold BD, Gessner BD. Endemic iron deficiency associated with Helicobacter pylori infection among school-aged children in Alaska. Pediatrics 2006;117(03): e396-e404

58 Hudak L, Jaraisy A, Haj S, Muhsen K. An updated systematic review and meta-analysis on the association between Helicobacter pylori infection and iron deficiency anemia. Helicobacter 2017;22(01): 12330-12333

59 Zahmatkeshan M, Karimi M, Geramizadeh B, Eslaminasab S, Esmailnejad A, Safarpour AR. Association between Helicobacter pylori infection and iron deficiency anemia in school-aged Iranian children. Indian Pediatr 2019;56(05):387-389

60 Sarker SA, Mahmud H, Davidsson L, et al. Causal relationship of Helicobacter pylori with iron-deficiency anemia or failure of iron supplementation in children. Gastroenterology 2008;135(05): 1534-1542

61 Vendt N, Kool P, Teesalu K, Lillemäe K, Maaroos HI, Oona M. Iron deficiency and Helicobacter pylori infection in children. Acta Paediatr 2011;100(09):1239-1243

62 Santos IS, Boccio J, Davidsson L, et al. Helicobacter pylori is not associated with anaemia in Latin America: results from Argentina, Brazil, Bolivia, Cuba, Mexico and Venezuela. Public Health Nutr 2009;12(10):1862-1870

63 El-Kady HM, Al-Kahiry W, Abdelsalam HS. Burden of Helicobacter pylori infections and associated risk factors among cases of iron deficiency anaemia in Egypt. Microbiol Res J Int 2020:80-91

64 Osman HA, Hasan H, Suppian R, et al. Evaluation of the Atlas Helicobacter pylori stool antigen test for diagnosis of infection in adult patients. Asian Pac J Cancer Prev 2014;15(13):5245-5247

65 Shatla MM. Treatment of Helicobacter Pylori associated iron deficiency anemia: does iron supplementation make difference. Eur J Preventive Med 2016;4(02):50-55

66 Abou-Taleb A, Allam A, Elsamman M. Association between Helicobacter pylori infection and iron deficiency anemia among school-age children in Sohag University hospital, Upper Egypt. Open J Blood Dis 2017;7:36-46

67 Queiroz DMM, Harris PR, Sanderson IR, et al. Iron status and Helicobacter pylori infection in symptomatic children: an international multi-centered study. PLoS One 2013;8(07):e68833

68 Muhsen K, Barak M, Henig C, Alpert G, Ornoy A, Cohen D. Is the association between Helicobacter pylori infection and anemia age dependent? Helicobacter 2010;15(05):467-472

69 Afifi RA, Ali DK, Shaheen IA. A localized case-control study of extra-gastric manifestations of Helicobacter pylori infection in children. Indian J Pediatr 2011;78(04):418-422

70 Soylu ÖB, Ozturk Y. Helicobacter pylori infection: effect on malnutrition and growth failure in dyspeptic children. Eur J Pediatr 2008;167(05):557-562 
e326 Helicobacter pylori Infection among Anemic School-Age Children Abdelaziz et al.

71 Sh M, Al-Ani MH. Coexistence of iron deficiency anemia with Helicobacter pylori infection among children aged 6 to 12 years in Erbil city. Med J Tikrit Univers 2019;25(02):121-130

72 Haghi-Ashtiani MT, Monajemzadeh M, Motamed F, et al. Anemia in children with and without Helicobacter pylori infection. Arch Med Res 2008;39(05):536-540

73 Hoseinzadeh M, Khosravi A, Sayemiri K, Rasoli MH, Mohaveri A. The antibody titers to Helicobacter pylori in $7-12$ year old iron deficiency anemic children, in Ilam. J Res Med Sci 2010;15(06): 324-330
74 Chiu NC, Lin CY, Chi H, et al. Helicobacter pylori infection is not associated with failure to thrive: a case control study. Ther Clin Risk Manag 2017;13:273-278

75 Gravina AG, Zagari RM, De Musis C, Romano L, Loguercio C, Romano M. Helicobacter pylori and extragastric diseases: a review. World J Gastroenterol 2018;24(29):3204-3221

76 Zhang $\mathrm{F}, \mathrm{Pu} \mathrm{K}, \mathrm{Wu} \mathrm{Z}$, et al. Prevalence and associated risk factors of Helicobacter pylori infection in the Wuwei cohort of north-western China. Trop Med Int Health 2021;26(03): 290-300 